\title{
Geographic Information Systems Applications in the Tourism Planning of Archaeological Sites in Fatimid Cairo
}

\author{
Hany Ahmed Aly Ibrahim Khattab ${ }^{1, *}$, Ramadan Ahmed Mohammed El-Sayed ${ }^{2}$ \\ ${ }^{1}$ Tourism Department, Faculty of Tourism and Hotels, October 6 University, Egypt \\ ${ }^{2}$ Tourism Guidance Department, Faculty of Tourism and Hotels, October 6 University, Egypt
}

Received March 22, 2021; Revised May 12, 2021; Accepted September 20, 2021

\section{Cite This Paper in the following Citation Styles}

(a): [1] Hany Ahmed Aly Ibrahim Khattab, Ramadan Ahmed Mohammed El-Sayed, "Geographic Information Systems Applications in the Tourism Planning of Archaeological Sites in Fatimid Cairo," Environment and Ecology Research, Vol. 9, No. 5, pp. 242 - 260, 2021. DOI: 10.13189/eer.2021.090505.

(b): Hany Ahmed Aly Ibrahim Khattab, Ramadan Ahmed Mohammed El-Sayed (2021). Geographic Information Systems Applications in the Tourism Planning of Archaeological Sites in Fatimid Cairo. Environment and Ecology Research, 9(5), 242 - 260. DOI: 10.13189/eer.2021.090505.

Copyright $\odot 2021$ by authors, all rights reserved. Authors agree that this article remains permanently open access under the terms of the Creative Commons Attribution License 4.0 International License

\begin{abstract}
Geographic Information Systems (GIS) is one of the modern methods that contributed extensively to facilitating the tasks and performance of planners during decisions related to the development or analysis of a particular problem with a spatial dimension, and this technique has been used in many different scientific fields such as the study of the distribution of services, analysis of land uses, or the division of transportation. The paper aims to highlight the benefits of Geographic Information Systems (GIS) in tourism planning, identify the basic stages of Geographic Information Systems (GIS) applications in tourism planning, and to identify the importance of using Geographic Information Systems (GIS) in the tourism planning of archaeological sites in Fatimid Cairo. This study was based on a descriptive analytical approach and the field survey method was applied in the sample method to reach conclusions that serve the objectives of the study. This study was finalized by several results, most notably: The need to use Geographic Information Systems (GIS) in documenting the monuments by transferring all images, data and written inscriptions on them and illustrating them through pictures and videos, to form a database to be available to the tourist, researcher and planner. The planning of archaeological sites using Geographic Information Systems (GIS) in the study area (Fatimid Cairo), saves time and effort by relying on aerial and space images and topographic maps with high accuracy and
\end{abstract}

conducting analysis and reaching accurate results in a very short period, compared to the time required using traditional methods.

Keywords Geographic Information Systems (GIS), Tourism Planning, Fatimid Cairo

\section{Introduction}

The development of the tourism sector needs to compact strategic planning, considering environmental considerations, available resources, and tourism possibilities, so the researchers end up by the necessity of planning, implementing and managing all the planning levels with a correct scientific approach and special programs to account for existing possibilities and how to exploit them optimally (Moyle et al, 2020).

Planning must have a huge amount of accurate and detailed information relevant to the land and the process of collecting, organizing, analyzing, showing, and coordinating information has become large in a system that allows it to be called easily, easily, and quickly acceptable and forms geographic information systems, Geographic Information Systems (GIS) (Tomaszewski, 2020). A new developed scientific and important tool is 
preserving geographical information about the nature of places, also by monitoring and analysis of all resources, and focusing on the effects of tourism development (Maldonado-Erazo et al, 2021).

The archaeological sites in Cairo governorate represent a study area that needs research interest based on the technology of the geographical information system, due to the complexity of the functional structure of the region, and the importance of the area archaeologically, where the tourist constituents vary in the study area, and thus the potential of the proposed system in the management and development of heritage and archaeological mosques has been demonstrated.

\section{Materials and Methods}

\subsection{Research Problem}

The problem of research is crystallized in the low level of awareness and interest in the information infrastructure of data for geographic information systems Geographic Information Systems (GIS) in the tourism field, which shows weakness and deficiencies in tourism plans and their incompatibility with the actual reality as a result of the lack in data collection and inventory and recording in a coordinated and scientific manner and documentation in a new technological method by using computer systems through using specialized programs in the process of data collection, illustrations, charts and all contents, whether digital data or graphics where it provides a realistic image of the shortcomings and available possibilities, exploited services that must be provided in the tourist and archaeological areas and then displayed on the tourist map in a coordinated and planned manner, because the data create a fundamental base for tourist planning.

The study attempts to answer the following questions:

How do Geographic Information Systems (GIS) applications help in the tourism planning?

Are Geographic Information Systems (GIS) applications used in Cairo's archaeological sites tourism plan?

\subsection{Objectives Research}

The research aims to: -

1. Highlight the benefits of Geographic Information Systems (GIS) in tourism planning

2. Identify the basis stages of Geographic Information Systems (GIS) applications in tourism planning

3. Identify the importance and using of Geographic Information Systems (GIS) in the tourism planning of archaeological sites in Fatimid Cairo

\subsection{The Importance of the Study}

The importance of the study is to document the landmarks by the using of Geographic Information Systems (GIS) through transferring all images, data and written inscriptions on them and containing them in pictures and video, to form a database in order to become available to the tourist, researcher and planner.

\subsection{Research Methodology}

This study was based on a descriptive analytical approach that is based on the study of the phenomenon as it actually exists and is concerned with it description accurately, and the field survey method was applied in the sample method in order to reach conclusions that serve the objectives of the study.

Data collection tools: theoretically relevant data collection tools: include sources and references and discussion some results and studies related to study variables. As well as the tools of collecting data related to the field aspect and the data of the study were collected by the questionnaire through the personal interviews, where a small random sample was selected from the study community represented by employees in the Ministry of Tourism and Antiquities, the Ministry of Communications and the Institute of National Planning.

\subsection{Limits of Research}

Spatial boundaries: The boundaries of spatial research included the geographical boundaries for tourism and planning development in Egypt by selecting Fatimid Cairo as a model for applying the uses of Geographic Information Systems (GIS) on the region.

Time limits: The field study was conducted from January 2021 to February 2021.

\subsection{Geographic Information Systems (GIS) Definitions}

A geographic information system is a special case of information systems that contain information databases based on the study of the spatial distribution of phenomena, activities and goals that can be determined spatially, such as points, lines, or areas to make the data ready for retrieval and analysis or inquiring about data through it (Turer, 2020).A geographic information system is a technology system for information that stores, analyzes and displays all domain and non-domain information(Kurowksa et al, 2021).Geographic Information Systems (GIS) is a database system that contains systematic information, as well as a set of processes that answer queries about a domain phenomenon from the information base. "Dangol and Hacigüzeller, 2021).Geographic Information Systems (GIS) is a group of information equipment, software and automated functions that enable the storage, management, analysis, modelling and presentation of data related to their geographical sites to solve complex problems associated with planning and management (Xu, 2021).It is 
clear from previous definitions that Geographic Information Systems (GIS) is a system with a field reference and includes a group of hardware and software that allows the user to perform a set of tasks, such as data entry from different sources (maps, aerial images, satellite images...) storage, organization, management, analysis, presentation and output of data and information in various forms (maps, diagrams, tables and reports).

\subsection{Benefits of Uses of Geographic Information Systems (GIS)}

The benefits of Geographic Information Systems (GIS) are to keep information clearly and definitively absorbing phenomena and control the dangers of providing data and information on Geographic Information Systems (GIS) and facilitate their access to decision makers in the administrations of state agencies, the planning sector and the economy, especially investors, as well as help Geographic Information Systems (GIS) facilitate the mapping process no matter how large and high lye so that people can use it in their work, and facilitate the process of preserving data with large maps inside the computer so that they can easily access and make adjustments and these are perhaps the most important benefits of the system(Schade et al, 2020).Also, one of the benefits of the uses of Geographic Information Systems (GIS)is the ease of showing data on maps without having to manually slide it where the required data are displayed in the form that the user needs and with great ease. It is also easy to back up data and maps and use them when needed. In the area of water networks, Geographic Information Systems (GIS) can identify faulty locations in areas with water outages, as well as around sewers and infrastructure, which can easily identify blockages. Another system without any noticeable error (Kates and Coryn, 2021).

There are a lot of benefits of Geographic Information Systems (GIS) Applications in Tourism Planning. GIS provide information to decision makers in addition to taking actions based on accurate and information, which is reflected on tourism planning in encouraging tourism investments (Minasi et al, 2020). Also, Geographic Information Systems (GIS)are characterized in tourism planning as an electronic archive of geographical information, in terms of sites and data of tourist places, and the ability to save large amounts of information so that it can be used with ease and in very quickly time (Devkota et al, 2019).As well, Geographic Information Systems (GIS)consider the primary warning device in the process of monitoring many natural phenomena such as natural disasters and environmental pollution, allowing decision makers to access the rapid and visual decision of vital information on the location of the crisis, which helps to develop the action plans that are printed or sent to the team work to deal with the crisis and thus it helps to coordinate and activate emergency efforts, as well as enable it to identify natural resources, extrapolating tourism demand and present the solutions to address problems, which is what the tourism sector needs in all tourist and archaeological sites(Zhou et al, 2021).Furthermore, the use of Geographic Information Systems (GIS) effectively contribute tothe tourism planning and contributes positively to determining future needs, saving costs compared to other means such as aerial photography and ground surveying (Lü et al, 2019).

\section{8. (GIS) Applications in the Tourism Planning}

The traditional methods used in tourism planning are characterized by limited capacity in the operation of processing and analysis. It relies on paper maps as hardcopy manuals, takes a lot of effort and time, does not enable the planner to take all the natural blacksmiths into account, and does not give variety of options and planning alternatives that can be implemented by using Geographic Information Systems (GIS), easily and through the study of applied cases of Geographic Information Systems (GIS) uses in tourist planning, and which focused on many of the advantages and disadvantages resulting from the traditional work in tourism planning, where it works to save effort and time. Also it gives the possibility of changing characteristics and objectives to be more flexible and provides a lot of alternatives and options with providing accurate results but at the same time it needs to merge between the planning thinking and experience in the use of IT applications, and the ability to use Geographic Information Systems (GIS) software in addition to the availability of financial capabilities to buy software and equipment (Aminu et al, 2013).

Digitalization contributes to the conservation of heritage and scientific resources; it can be used to encourage tourism, and it provides ways of improving access by citizens to their patrimony. Intangible tourism services cannot be physically displayed or inspected at the point of sale before purchasing, and so the tourism product is dependent upon information in printed and audio-visual form (Abdo, 2019).

\section{The Main Stages of Geographic Information Systems (GIS)}

First, identify the area to be planned and developed:

In the first phase of the construction of the proposed Geographic Information Systems (GIS) systems, the geographical scope is determined and the boundaries of the target region are identified and applied to it, thus facilitating the knowledge of ground units and their characteristics, as well as knowledge of geomorphological processes such as hydroponic and air erosion, environmental hazards, flood streams, valleys, rift areas, joints, land folds, agricultural and urban areas that affect the tourist facilities.(Krois and Schulte, 2014). 
Secondly, laying the foundations and planning criteria:

After identifying the natural determinants of the planned area, it would be necessary to establish the basis and plan criteria to deal with those determinants and factors (Yousefi et al, 2019).

Third, collecting and classifying the data used in the proposed system:

After determining the study area, the data are collected and entered the database and the system Geographic Information Systems (GIS) can deal with many types of metadata and geographical data, and space and aerial images are considered one of the most important sources of tourist data for the proposed area (Burrough et al. 2015).

Fourth, system and analysis design

The Geographic Information Systems (GIS) analysis and design phase includes three stages: (Burrough et al. 2015).

A. System analysis phase.

B. System design phase.

C. The phase of data base physical conceptual design.

The steps of the system analysis phase are including the proposed system by using the structural method of analysis and design Geographic Information Systems (GIS), through \{Structured system analysis and design method / SSADM $\}$. The last step in the analysis and design of the system involves processing the database in terms of identifying and evaluating its component, identification of contents of data base and coordinate system (Burrough et al. 2015).

Fifth, building applications, show and evaluate the results:

Geographic Information Systems (GIS) contains several modules subsystems, with single functions, integrated with other subsystems to eventually form the main system structure to achieve the main objectives (Yousefi et al, 2019).

Geographic Information Systems (GIS) applications in the tourism planning of archaeological sites in Fatimid Cairo.

Fatimid Cairo is one of the most important landmarks of religious tourism in Egypt, where it is characterized by tourists, which are represented by archaeological mosques dating back to the Fatimid period and successive Islamic times. Fatimid Cairo needs good planning that takes in concern all the environmental, social and economic dimensions and is carried out through the applications of modern technologies represented by geographical information systems. Geographic Information Systems (GIS) in contributing to tourism planning in terms of collecting and accounting data and the work of maps and providing them, choosing the most suitable tourist sites and preparing them and identifying the resources that can be exploited in a sustainable way to ensure the preservation of resources for future periods in addition to preserving the environment and attracting more tourists to raise the level of international and local tourist demand in a balanced way in order to contribute to the easing of the seasonal of Fatimid Cairo.

\subsection{Geographical Boundaries of the Study Area}

The proposed area of the study has a historical and international reputation because it is considered the heritage complex of Cairo since its construction. The proposed area of the study is in the western part of al-Jamalia's district, al-Muizz street is the most famous street in Fatimid Cairo, with its archaeological and heritage sites dating back to Fatimid, Ayyubid, Mamluk, Ottoman and Muhammad Ali Pasha periods (Morsi, 2008).

Geographic Information Systems (GIS) objectives in the tourism planning of archaeological sites in Fatimid Cairo are the preservation of buildings and heritage sites through, the conception of geography through aerial photographs and maps to identify the neglected Islamic heritage buildings and how to exploit, integrate and use them in tourism field, finding economic sources of financing, preserve these buildings and restore the dilapidated ones, maintaining the original functions of the Islamic archaeological buildings used so that the area does not lose its value, the dealing with Islamic archaeological buildings according to the conditions of each building in terms of maintenance, restoration, protection and re-employment, the visual upgrading of Islamic buildings and archaeological sites and surrounding areas and the removal of any encroachments or negative impacts affecting Islamic archaeological areas, the ability to predict and control urban growth in the areas around the Islamic archaeological area by collecting and entering data and information can be identified to preserve the privacy of residential areas in terms of social activities, traditions and local culture, by avoiding tourist services in residential areas, the upgrading the urban surrounding Islamic archaeological buildings, the optimum land use, the control of the development strategy and policy and address the causes of negative impacts such as congestion, visual pollution, and air pollution, identify road networks to tourist sites and Islamic archaeological sites and provide elements of the infrastructure of the region, which contributes to the upgrading of the social and economic structure.

\subsection{Archaeological Assets in Fatimid Cairo}

Cairo has the highest value amid the world's historic cities, where it is characterized by its distinctive urban heritage that has grown over a thousand years. Cairo was the pride of architects and scholars and more over it as a 
living urban heritage that is still pulsating and interacting with the cultural and civilizational inventory. Fatimid Cairo has many archaeological features and Islamic monuments (as shown figure 1), whether they date back to the Fatimid period, the Ayyubid period, the Mamluk period, the Ottoman era and the Muhammad Ali's dynasty. The most important Islamic monuments in Fatimid Cairo (Al-Muizz li din Allah Street) are Bab al-Futuh, Bab al-Nasr, Mosque of al-Hakim bi-Amr Allah, Wikalat Sultan al-Ashraf Qaytbay, Beit al-Sehemy, Mosque of Al-Aqmar, Sabil and kuttab of Abd al-Rahman Katkhuda, Amir Bashtak Palace, Complex of Sultan al-Mansour Qalawun, Sabil and kuttabKhusrow Pasha, Madrasa of Sultan al-Ashraf Presbay, Wikalat of Sultan Qansuh al-Ghouri, Mosque of al-Fakahani, Mosque of Sabil and kuttab of Sheikh Ali al-Mutahar, Sabil Muhammad Ali Pasha Belaqadin, Beit al-Shabashiri, Mosque of Sultan al-Muayyad Sheikh, Sabil and WikalatNafisa al-Bayda, Bab Zuwayla, Mosque of al-SalihTalai, and Zawya Sultan Nasser Faraj bin Barquq (Ministry of Culture, 2015)

The proposed outputs of the geographical database of archaeological sites in the study are through the map's archaeological database, we can inquire about any event the user wants it for this system, and the database includes several tables in the form of fields dealing with the various aspects of the study area, the opening of the link of the hyperlink of any mosque and seeing all the information about it, the research by using the historical period where the application chooses all mosques dating back to a specific historical period, the possibility of the user searching for heritage and archaeological mosques in Cairo governorate under a specific classification, the possibility of inquiring about many issues within heritage and archaeological mosques, the possibility accessing to the heritage and archaeological mosques and show their plans, accompanied by written information, images and live video shots, the analysis of the network and finding the shortest route between two phenomena or tourist landmarks, the possibility of doing some statistical processes, such as calculating the number of mosques dating back to a specific historical period, the ability to enlarge any of the sites within the heritage and archaeological mosques in the digital map and finding a specific phenomenon or landmark where a dialogue box is shown for the user and asking him to enter the name of the heritage or archaeological mosque that he wishes to look for, and after finding the mosque the system allows for the user all the data and information about it. 


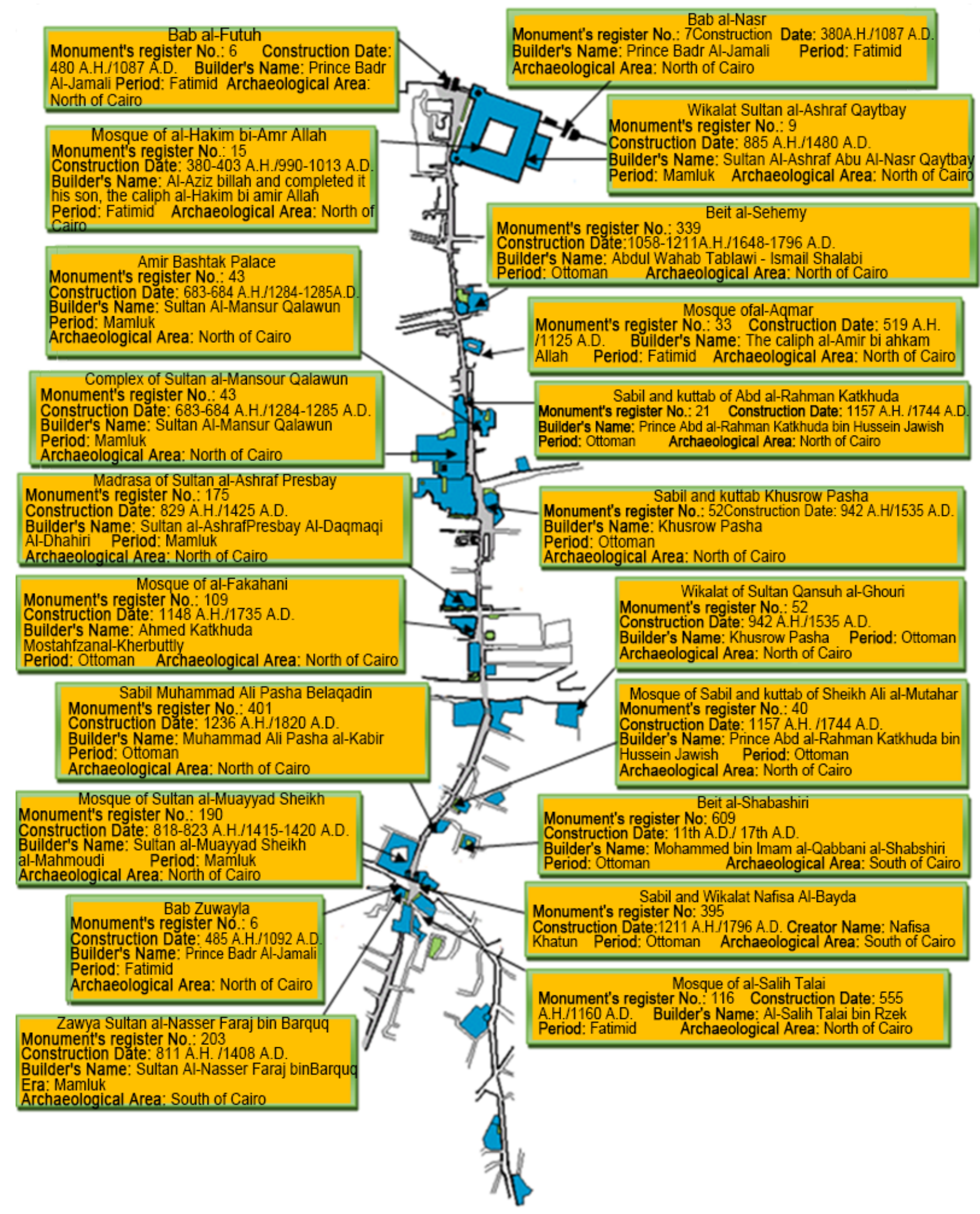

Figure 1. A detailed map of the most important Archaeological and Heritage sites in Al-Muizz Street (Ministry of Culture, 2015) 


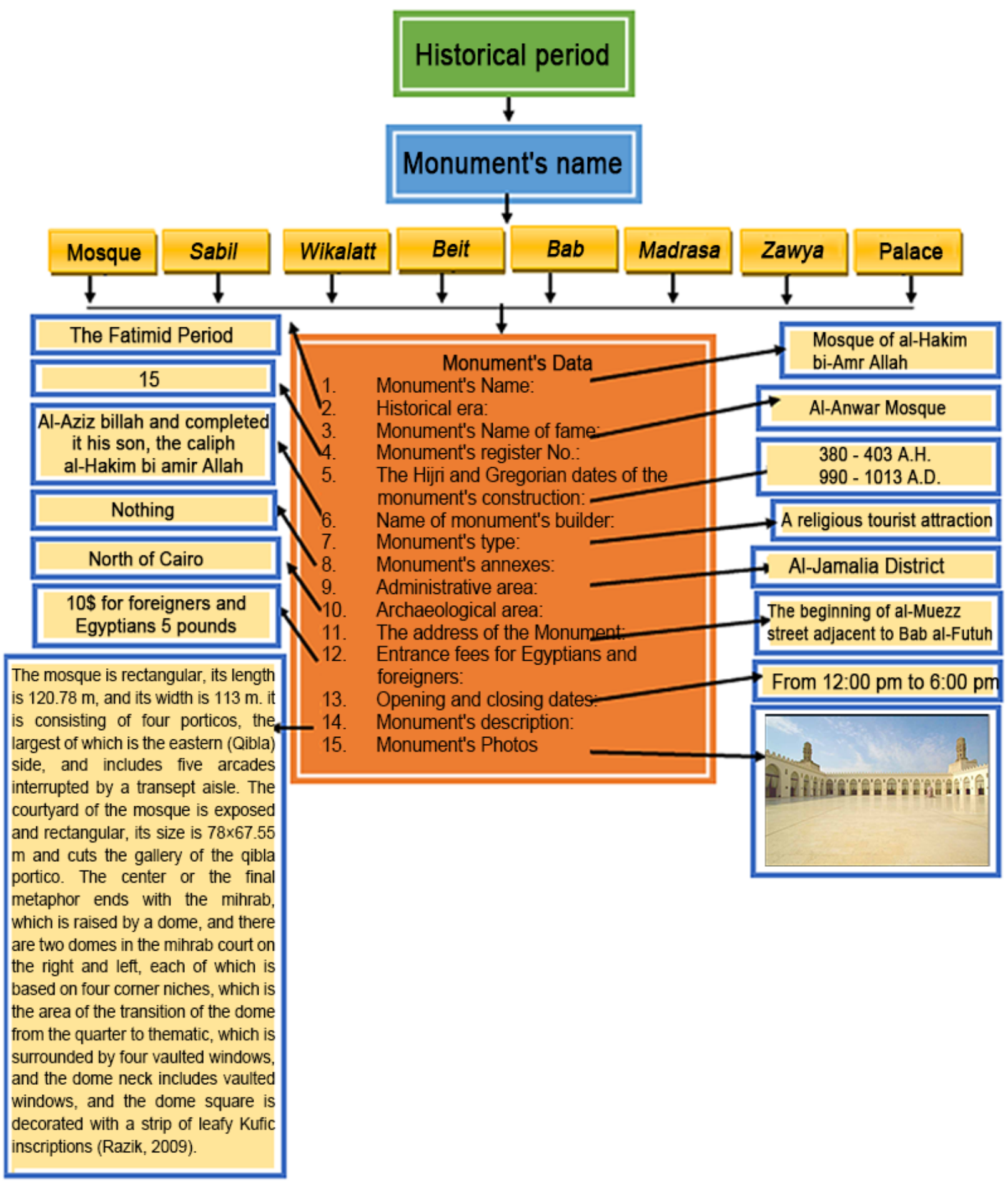

Figure 2. Program's Design of the Geographic Database (by the researchers) 


\subsection{Field Study Methodology}

This study was based on a descriptive analytical method that is relied on the study of the phenomenon as it exists and is concerned with an accurate description, and the field survey method was applied in the sample way in order to reach to conclusions that serve the objectives of the study.

Data collection tools: data collection tools relevant theoretically: include sources and references and discussion some results and studies related to study variables. As well as the tools of collecting data related to the field aspect and the data of the study were collected by the questionnaire through the personal interviews, where a small random sample was selected from the study community represented by employees in the Ministry of Tourism and Antiquities, the Ministry of Communications and the Institute of National Planning.

\section{Identification of the Survey Community}

The study community consists of employees in the official specialized entities represented by the Ministry of Tourism and Antiquities, the Ministry of Communications, and the National Planning Institute to analyze and study the current situation of Geographic Information Systems (GIS) uses and their application in the field of tourism and specifically in tourism planning in Egypt.

This study was based on a random method in selecting the study sample, where a simple random sample was selected from the study community. The size of the sample of the study of the employees specialized official entities represented by the Ministry of Tourism and Antiquities, the Ministry of Communications and the National Planning Institute is (360) and the number of valid questionnaires for statistical analysis is (300) questionnaires.

\section{Using the Pentagram Likert}

The Likert's pentagrams are generally used to determine the overall response levels of respondents to the responses to the graded rejection and acceptance questions known as the pentagram Likert(Strongly agree - agree neutral - strongly refuse) the pentagram Likert has been used to determine the levels of answer to questionnaire questions, and The Likert method is a commonly used method in measuring the scientific trends and the social researches, for its short the time and the effort, and the Likert pentagram is distinguished by the facility in the design, apply, correction and high degree of its consistency and accuracy.

The five directions of the opinions of the respondents within the Statistical Program SPSS were coded to determine the level of their approval or rejection on the content of the questions in the main themes as well as the following table:
Table 1. The Relative Weight of Respondents' Opinions

\begin{tabular}{|c|c|c|c|c|c|}
\hline Opinion & $\begin{array}{c}\text { Strongly } \\
\text { Disagree }\end{array}$ & Disagree & Neutral & Agree & $\begin{array}{c}\text { strongly } \\
\text { agree }\end{array}$ \\
\hline $\begin{array}{c}\text { Relative } \\
\text { weight }\end{array}$ & 1 & 2 & 3 & 4 & 5 \\
\hline
\end{tabular}

From the previous table, the full approval of the respondents takes code number (5) while the total refusal takes code number (1) and the answers range from two codes to be the length of one category equal to 0.80 , and the following table shows the value of the weighted average, relative weight and level of approval or rejection according to the opinions of the respondents.

Table 2. Weighted Average Value and Relative Weights of the Respondents' Opinions

\begin{tabular}{|c|c|c|c|}
\hline Description & $\begin{array}{c}\text { Weighted } \\
\text { average value }\end{array}$ & $\begin{array}{c}\text { Relative } \\
\text { weight }\end{array}$ & $\begin{array}{c}\text { Response } \\
\text { level }\end{array}$ \\
\hline Disagree & $\begin{array}{c}\text { From } 1 \text { to less } \\
\text { than } 1.8\end{array}$ & $\begin{array}{c}\text { Less than } \\
36 \%\end{array}$ & Very low \\
\hline Disagree & $\begin{array}{c}\text { From } 1.8 \text { to less } \\
\text { than } 2.6\end{array}$ & $\begin{array}{c}\text { From } 36 \% \text { to } \\
\text { less than } 52 \%\end{array}$ & Low \\
\hline Neutral & $\begin{array}{c}\text { From } 2.6 \text { to less } \\
\text { than } 3.4\end{array}$ & $\begin{array}{c}\text { From } 52 \% \text { to } \\
\text { less than } 68 \%\end{array}$ & Average \\
\hline Agree & $\begin{array}{c}\text { From } 3.4 \text { to less } \\
\text { than } 4.2\end{array}$ & $\begin{array}{c}\text { From } 68 \% \text { to } \\
\text { less than } 84 \%\end{array}$ & High \\
\hline strongly agree & From 4.2 to 5 & $\begin{array}{c}\text { More than } \\
84 \%\end{array}$ & Very high \\
\hline
\end{tabular}

From the previous table, it is clear that mathematical averages and relative weights can be relied on it to give a clear weighting indication on the averages that are below about (1.8) indicate the level of approval from the point of view of the sample members of the study as the paragraphs or questionnaire axes are very low, while the calculation averages ranging from (1.8 to less than 2.6) indicate a low degree of approval, while the averages that Ranging from (2.6 to less than 3.4) in indicative of an average approval level, while averages ranging from (3.4 to less than 4.2) indicate a high approval level, while averages ranging from (4.2 to less than 5) indicate a very high level, and this division is classified according to the pentagram Likert adopted in the study tool. The questionnaire was divided into two axes to include each axis a group of paragraphs that were formulated to answer the study's questions for the reaching to the objectives of the study.

\section{Measuring the Truth of the Stability and Credibility of the Questionnaire}

To confirm the validity of the questions placed in the questionnaire before starting to be distributed to ensure the success of the process of collecting the required data from the selected sample so that the study ensures that the sample can represent the study community in all categories and characteristics, where the survey form was presented to a group of specialists in the field of the subject of the study, in order to give the opinion on the terms used and the way the questions were formulated as 
well as the extent to which they relate to the subject of the study, and accordingly the wrong questions or phrases are cancelled.

Alpha Cronbach's test: -or internal consistency test of the form: it is one of the most important tests used to measure the stability of the questionnaire score, and this test is used to determine whether the questionnaire questions are correct in the light of the experts' responses and according to the test results the questions are modified or maintained as they are.

The test was carried out on the questionnaire after its adjusting according to the results of the clarified previous method of operation and ensuring its integrity and consistency. The validity and consistency of the study questionnaire was verified for the study, and the results were as indicated in the following table:

Table 3. Alpha Cronbach Questionnaire Stability Factor

\begin{tabular}{|c|c|c|}
\hline Axis & $\begin{array}{c}\text { Number of } \\
\text { paragraphs }\end{array}$ & $\begin{array}{c}\text { Alpha } \\
\text { Cronbach } \\
\text { Laboratories }\end{array}$ \\
\hline $\begin{array}{c}\text { The first axis(the impact of } \\
\text { Geographic Information Systems } \\
\text { (GIS) applications on tourism } \\
\text { planning) }\end{array}$ & 9 & 0.932 \\
\hline $\begin{array}{c}\text { The second axis (assessing the } \\
\text { current situation of the use of } \\
\text { Geographic Information Systems } \\
\text { (GIS) in the tourism planning for } \\
\text { archaeological sites in Fatimid } \\
\text { Cairo) }\end{array}$ & 10 & 0.861 \\
\hline Total & 19 & 0.915 \\
\hline
\end{tabular}

The results of the Alpha-Cronbach test confirmed the practical method that is used to confirm the stability of the questionnaire paragraphs, with the value of the coefficient ranging from $(0.861,0.932)$ and the value of the Alpha Cronbach coefficient for the form (0.915) and its proximity to the correct one, indicating that the questionnaire took a high degree of stability in the data collected from the sample members of the study.

\subsection{The Used Statistical Tools}

To achieve the objectives of the study and analysis the collected data, the study used appropriate statistical methods using Statistical Packages for Social Sciences, which are coded by the symbol (SPSS), after the data were encoded and entered the computer, after that the following statistical measures were used and applied:

1) Alpha Cronbach's stability coefficient to measure thestability of the survey axes.

2) Repetitions and percentages to identify the sample responses toward the phrases of the main axes included in the survey.

3) Arithmethic meansto determine the extent of the high or the lowof the responses of the study sample members about the phrases of questionnaire axes, although it is useful in arranging the axes according to the highest arithmethic.

4) Standard Deviationto determine the extent to which the responses of the study sample members to each of the questionnaire phrases, and each of the main axes fortheir arithmetic mean, it is noted that the standard deviation indicates the dispersion inthe responses of the study sample members for each questionnaire, as well as the main axes, whenever its value closed from the zero the responses are focused and the less dispersion between the scale.

\subsection{The Study Outputs}

The first axis: (the impact of Geographic Information Systems (GIS) applications on tourism planning)

The First Paragraph: The extent of determination of the planning objectives of the tourist areas clearly the result of the opinions of the sample was as shown in table 4 .

It is noted from table data (4) that the total of the opinions of the sample (strongly agree and Agree) of 266 individuals with a percentage $88.7 \%$ are the opinions that tend to be clearly determined by the responsible authorities in determining the planning objectives of the tourist areas compared to the total of the opinions (Strongly Disagree and Disagree) which amounted to 18 individuals with a percentage $6 \%$. The results of the statistical analysis also showed that the average was 4.31 and the standard deviation was .908 that the approval level is very high.

The Second paragraph: The Authority/Ministry uses Geographic Information Systems (GIS) technology in tourism planning in Egypt.

The sample's answers were as shown in table 5 .

Table 4. Statistical Analysis (the extent of determination of the planning objectives for tourist areas clearly)

\begin{tabular}{|c|c|c|c|c|c|}
\hline \multicolumn{1}{|c|}{} & Iteration & Percentage & Arithmetic mean & Standard deviation \\
\hline \multirow{4}{*}{ Analyzable } & Strongly Disagree & 7 & $\% 2.3$ & & \\
\cline { 2 - 4 } & Disagree & 11 & $\% 3.7$ & \multirow{2}{*}{4.31} & \multirow{2}{*}{.908} \\
\cline { 2 - 5 } & Neutral & 16 & $\% 5.3$ & \\
\cline { 2 - 4 } & Agree & 113 & $\% 37.7$ & \\
\cline { 2 - 4 } & strongly agree & 153 & $\% 51.0$ & \\
\cline { 2 - 4 } & Total & 300 & $\% 100.0$ & & \\
\hline
\end{tabular}

Source: SPSS Outputs 
Table 5. Statistical Analysis (The Extent of the Authority/Ministry Using Geographic Information Systems (GIS) Technology in Tourism Planning in Egypt)

\begin{tabular}{|c|c|c|c|c|c|}
\hline & & Iteration & Percentage & Arithmetic mean & Standard deviation \\
\hline \multirow{6}{*}{ Analyzable } & Strongly Disagree & 171 & $\% 57.0$ & \multirow{6}{*}{2.38} & \multirow{6}{*}{1.89} \\
\hline & Disagree & 95 & $\% 31.7$ & & \\
\hline & Neutral & 16 & $\% 5.3$ & & \\
\hline & Agree & 13 & $\% 4.3$ & & \\
\hline & strongly agree & 5 & $\% 1.7$ & & \\
\hline & Total & 300 & $\% 100.0$ & & \\
\hline
\end{tabular}

Source: SPSS Outputs

Table 6. Statistical Analysis (Are there other uses of Geographic Information Systems (GIS) techniques in tourism in general other than tourism planning)

\begin{tabular}{|c|c|c|c|c|c|}
\hline \multicolumn{1}{|c|}{} & Iteration & Percentage & Arithmetic mean & Standard deviation \\
\hline \multirow{4}{*}{ Analyzable } & Strongly Disagree & 175 & $\% 58.3$ & \\
\cline { 2 - 4 } & Disagree & 93 & $\% 31.0$ & \\
\cline { 2 - 4 } & Neutral & 14 & $\% 4.7$ & \multirow{2}{*}{2.39} & \multirow{2}{*}{1.94} \\
\cline { 2 - 4 } & Agree & 11 & $\% 3.7$ & \\
\cline { 2 - 4 } & strongly agree & 7 & $\% 2.3$ & \\
\cline { 2 - 5 } & Total & 300 & $\% 100.0$ & & \\
\hline
\end{tabular}

Source: SPSS Outputs

It should be noted from table data (5) that the total of the opinions of the sample (strongly Disagree and Disagree) number edited 266 individuals by $88.7 \%$ tend to disapprove of the second paragraph compared to the total of the opinions (strongly agree and agree) which amounted to 18 individuals by $6 \%$.

The descriptive analysis also showed that the average was 2.38 and the standard deviation was 1.89 , the approval level (very low).

The Third Paragraph: There are other uses of Geographic Information Systems (GIS) techniques in tourism in general other than tourism planning.

The sample's answers were as shown in table 6 .
It is noted from table data (6) that the total of the opinions of the sample (Strongly Disagree and Disagree) number edited 268 individuals with $89.3 \%$ are opinions that tend to be disapproved compared to the total of the opinions (strongly agree and agree) which amounted to 18 individuals by $6 \%$.

The results of the descriptive analysis also showed that the average was 2.39 and the standard deviation was 1.94 , the approval level (very low).

The Fourth Paragraph: There is a lack of use of Geographic Information Systems (GIS) in tourism planning in Egypt.

The sample's answers were as shown in table 7. 
Table 7. Statistical Analysis (the extent of a deficiency in the use of Geographic Information Systems (GIS) in tourism planning in Egypt)

\begin{tabular}{|c|c|c|c|c|c|}
\hline & & Iteration & Percentage & Arithmetic mean & Standard deviation \\
\hline \multirow{6}{*}{ Analyzable } & Strongly Disagree & 113 & $\% 37.7$ & \multirow{6}{*}{2.22} & \multirow{6}{*}{1.283} \\
\hline & Disagree & 97 & $\% 32.3$ & & \\
\hline & Neutral & 17 & $\% 5.7$ & & \\
\hline & Agree & 56 & $\% 18.7$ & & \\
\hline & strongly agree & 17 & $\% 5.7$ & & \\
\hline & Total & 300 & $\% 100.0$ & & \\
\hline
\end{tabular}

Source: SPSS Outputs

Table 8. Statistical Analysis (for the coordination between the concerned authorities with the tourism planning)

\begin{tabular}{|c|c|c|c|c|c|}
\hline & & Iteration & Percentage & Arithmetic mean & Standard deviation \\
\hline \multirow{6}{*}{ Analyzable } & Strongly Disagree & 115 & $\% 38.3$ & \multirow{6}{*}{2.19} & \multirow{6}{*}{1.246} \\
\hline & Disagree & 94 & $\% 31.3$ & & \\
\hline & Neutral & 23 & $\% 7.7$ & & \\
\hline & Agree & 55 & $\% 18.3$ & & \\
\hline & strongly agree & 13 & $\% 4.3$ & & \\
\hline & Total & 300 & $\% 100.0$ & & \\
\hline
\end{tabular}

Source: SPSS Outputs

From the table data No. (7) show that the total of the opinions of the sample (Strongly Disagree and Disagree) of 210 individuals with a percentage $70.0 \%$ tend to be disapproving compared to the total of the opinions (strongly agree and Agree) which were 73 individuals with a percentage $24.4 \%$. The results of the descriptive analysis also showed that the average was 2.22 and the standard deviation was 1.283 , that is, the approval level is low.

The Fifth Paragraph: The coordination between the concerned authorities with the tourism planning and the sample answers were as shown in table 8.
It is noted from table data (8) that the total of the opinions of the sample (Strongly Disagree and Disagree) of 209 individuals with a percentage $69.6 \%$ tend to be approved compared to the total of the opinions (strongly agree and agree) which were 68 individuals with a percentage $22.6 \%$. The results of the descriptive analysis also showed that the average was 2.19 and the standard deviation was 1.246 , that is, the approval level is low.

The Sixth Paragraph: It is based on the data and information available when developing tourist plans and the sample answers were as shown in table 9 . 
Table 9. Statistical Analysis (It is based on the data and information available when developing tourist plans)

\begin{tabular}{|c|c|c|c|c|c|}
\hline \multicolumn{1}{|c|}{} & Iteration & Percentage & Arithmetic mean & $\begin{array}{c}\text { Standard } \\
\text { deviation }\end{array}$ \\
\hline \multirow{4}{*}{ Analyzable } & Strongly Disagree & 4 & $\% 1.3$ & & \\
\cline { 2 - 4 } & Disagree & 6 & $\% 2.0$ & & \\
\cline { 2 - 4 } & Neutral & 7 & $\% 2.3$ & \multirow{2}{*}{4.31} & .736 \\
\cline { 2 - 5 } & Agree & 159 & $\% 53.0$ & & \\
\cline { 2 - 5 } & strongly agree & 124 & $\% 41.3$ & & \\
\cline { 2 - 5 } & Total & 300 & $\% 100.0$ & & \\
\end{tabular}

Source: SPSS Outputs

Table 10. Statistical Analysis (The extent of determination the Ministry/Authority clear steps for getting benefit from Geographic Information Systems (GIS).

\begin{tabular}{|c|c|c|c|c|c|}
\hline \multicolumn{1}{|c|}{} & Iteration & Percentage & Arithmetic mean & Standard deviation \\
\hline \multirow{4}{*}{ Analyzable } & Disagree. & 103 & $\% 34.3$ & & \\
\cline { 2 - 4 } & Strongly Disagree. & 158 & $\% 52.7$ & \multirow{2}{*}{2} \\
\cline { 2 - 4 } & Neutral & 24 & $\% 8.0$ & \multirow{2}{*}{2.33} & \\
\cline { 2 - 4 } & strongly agree. & 4 & $\% 1.3$ & \\
\cline { 2 - 4 } & Agree & 11 & $\% 3.7$ & \\
\cline { 2 - 4 } & Total & 300 & $\% 100.0$ & \\
\hline
\end{tabular}

Source: SPSS Outputs

It is noted from table data (9) that the total of the opinions of the sample (strongly agree and agree) of 283 individuals with $94.3 \%$ tend to be approved compared to the total of the opinions (Strongly Disagree and Disagree) which amounted to 10 individuals with a percentage $3.3 \%$. The results of the descriptive analysis also showed that the average was 4.31 and the standard deviation was 0.736 , that the approval level is very high.

The Seventh Paragraph: The extent of determination the Ministry/Authority clear steps for getting benefit from Geographic Information Systems (GIS).

It is noted from table 10 data that the total of the opinions of the sample (Strongly Disagree and Disagree) of 261 individuals with a percentage $87.0 \%$ tend to be disapproving compared to the total of the opinions (strongly agree and agree) which amounted to 15 individuals with a percentage $5.0 \%$.

The results of the descriptive analysis also showed that the average was 2.33 and the standard deviation was 1.87 , that the approval level is very high.

The Eighth Paragraph: The extent to which the responsible authorities organize training courses for employees to raise awareness of the applications of Geographic Information Systems (GIS)and the result of the opinions of the sample as shown in table 11. 
Table 11. Statistical Analysis (The Extent to Which the Responsible Authorities Organize Training Courses for Employees in Order to Raise Awareness of the Applications of Geographic Information Systems (GIS).

\begin{tabular}{|c|c|c|c|c|c|}
\hline & & Iteration & Percentage & Arithmetic mean & Standard deviation \\
\hline \multirow{6}{*}{ Analyzable } & Strongly Disagree & 186 & $\% 62.0$ & \multirow{6}{*}{1.58} & \multirow{6}{*}{.952} \\
\hline & Disagree & 88 & $\% 29.3$ & & \\
\hline & Neutral & 0 & $0 \%$ & & \\
\hline & Agree & 19 & $\% 6.3$ & & \\
\hline & strongly agree & 7 & $\% 2.3$ & & \\
\hline & Total & 300 & $\% 100.0$ & & \\
\hline
\end{tabular}

Source: SPSS Outputs

Table 12. Statistical Analysis (To what extent ownership of the study area for the elements of the tourist attractions)

\begin{tabular}{|c|c|c|c|c|c|}
\hline & & Iteration & Percentage & Arithmetic mean & Standard deviation \\
\hline \multirow{6}{*}{ Analyzable } & Strongly Disagree & 7 & $\% 2.3$ & \multirow{6}{*}{3.58} & \multirow{6}{*}{.952} \\
\hline & Disagree & 19 & $\% 6.3$ & & \\
\hline & Neutral & 0 & $0 \%$ & & \\
\hline & Agree & 88 & $\% 29.3$ & & \\
\hline & strongly agree & 186 & $\% 62.0$ & & \\
\hline & Total & 300 & $\% 100.0$ & & \\
\hline
\end{tabular}

Source: SPSS Outputs

It is noted from table data (11) that the total of the opinions of the sample (Strongly Disagree and Disagree) of 274 individuals with a percentage $91.3 \%$ tend to be disapproving compared to the total of the opinions (strongly agree and agree) which were 26 individuals with a percentage $8.6 \%$. The results of the descriptive analysis also showed an average of 1.58 and the standard deviation of .952 that the approval level is very low.

The Second Axis: (Assessing the Current Situation of the use of Geographic Information Systems (GIS) In the Tourism Planning for Archaeological Sites in Fatimid Cairo)

The First Paragraph: The study area has the elements of the tourist attractions and the result was of the opinions of the sample as shown in table 12 .

It is noted from table data (12) that the total of the opinions of the sample (strongly agree) of 274 individuals with a percentage $91.3 \%$ tend to be approved compared to the total of the two opinions (I strongly disagree with and agree) which amounted to 26 individuals by $8.6 \%$. The results of the descriptive analysis also showed an average of 3.58 and the standard deviation of .952 that the approval level is high.

The Second paragraph: The concerned authorities rely on Geographic Information Systems (GIS) for the tourism planning of the study area. The answers of the sample were as shown in table 13. 
Table 13. Statistical Analysis (he concerned authorities rely on Geographic Information Systems (GIS) for the tourism planning of the study area)

\begin{tabular}{|c|c|c|c|c|c|}
\hline & & Iteration & Percentage & Arithmetic mean & Standard deviation \\
\hline \multirow{6}{*}{ Analyzable } & Strongly Disagree & 8 & $\% 7.3$ & \multirow{6}{*}{1.63} & \multirow{6}{*}{1.84} \\
\hline & Disagree & 224 & $\% 74.7$ & & \\
\hline & Neutral & 32 & $\% 10.7$ & & \\
\hline & Agree & 22 & $\% 2.7$ & & \\
\hline & strongly agree & 14 & $\% 4.7$ & & \\
\hline & Total & 300 & $\% 100.0$ & & \\
\hline
\end{tabular}

Source: SPSS Outputs

Table 14. Statistical Analysis (Geographic Information Systems (GIS) contribute to increasing the tourism demand in the study area)

\begin{tabular}{|c|c|c|c|c|c|}
\hline & & Iteration & Percentage & Arithmetic mean & Standard deviation \\
\hline \multirow{6}{*}{ Analyzable } & Strongly Disagree & 10 & $\% 3.3$ & \multirow{6}{*}{3.76} & \multirow{6}{*}{.916} \\
\hline & Disagree & 26 & $\% 8.7$ & & \\
\hline & Neutral & 32 & $\% 10.7$ & & \\
\hline & Agree & 190 & $\% 63.3$ & & \\
\hline & strongly agree & 42 & $\% 14.0$ & & \\
\hline & Total & 300 & $\% 100.0$ & & \\
\hline
\end{tabular}

Source: SPSS Outputs

It is noted from table 13 data that the total of the opinions of the sample (Strongly Disagree and Disagree) of 232 individuals with a percentage $77.4 \%$ tend to be disapproving compared to the total of the opinions (strongly agree and agree) which amounted to 36 individuals with a percentage $12 \%$.

The results of the descriptive analysis also showed that the average was 1.63 and the standard deviation was 1.84 , that the approval level is high.

The Third Paragraph: GEOGRAPHIC INFORMATION SYSTEMS (GIS) contribute to increasing the tourist demand in the study area. The answers of the sample were as shown in table 14 .

It is noted from table data (14) that the total of the opinions of the sample (strongly agree and Agree) of 232 individuals with a percentage $77.3 \%$ tend to be approved compared to the total of the two opinions (Strongly Disagree and Disagree) which amounted to 36 individuals with a percentage $12 \%$. The results of the descriptive analysis also showed an average of 3.76 and the standard deviation of .916 that the approval level is high.

The Fourth Paragraph: There is a plan for the tourist development of the study area, and the sample answers were as shown in table 15 . 
Table 15. Statistical Analysis (There is a plan for the tourist development of the study area)

\begin{tabular}{|c|c|c|c|c|c|}
\hline & & Iteration & Percentage & Arithmetic mean & Standard deviation \\
\hline \multirow{6}{*}{ Analyzable } & Strongly Disagree & 10 & $\% 3.3$ & \multirow{6}{*}{3.81} & \multirow{6}{*}{.968} \\
\hline & Disagree & 28 & $\% 9.3$ & & \\
\hline & Neutral & 30 & $\% 10.0$ & & \\
\hline & Agree & 173 & $\% 57.7$ & & \\
\hline & strongly agree & 59 & $\% 19.7$ & & \\
\hline & Total & 300 & $\% 100.0$ & & \\
\hline
\end{tabular}

Source: SPSS Outputs

Table 16. Statistical Analysis (There is an applied system in the management of the study area by using Geographic Information Systems (GIS))

\begin{tabular}{|c|c|c|c|c|c|}
\hline & & Iteration & Percentage & Arithmetic mean & Standard deviation \\
\hline \multirow{6}{*}{ Analyzable } & Strongly Disagree & 17 & $\% 5.7$ & \multirow{6}{*}{1.22} & \multirow{6}{*}{1.84} \\
\hline & Disagree & 132 & $\% 44.0$ & & \\
\hline & Neutral & 59 & $\% 19.6$ & & \\
\hline & Agree & 92 & $\% 30.7$ & & \\
\hline & strongly agree & 0 & $0 \%$ & & \\
\hline & Total & 300 & $\% 100.0$ & & \\
\hline
\end{tabular}

Source: SPSS Outputs

It is noted from table data (15) that the total of the opinions of the sample (strongly agree and Agree) of 232 individuals with a percentage $77.3 \%$ tend to be approved compared to the total of the opinions (Strongly Disagree and Disagree) which amounted to 38 individuals with a percentage $12.6 \%$. The results of the descriptive analysis also showed an average of 3.81 and the standard deviation of .968 that the approval level is high.

The Fifth Paragraph: There is an applied system in the management of the study area by using Geographic Information Systems (GIS). The sample answers were as shown in table 16.

It is noted from table 16 data that the total of the opinions of the sample (Strongly Disagree and disagree) of 149 individuals with a percentage $49.7 \%$ tend to be disapproving compared to the total of the opinions (strongly agree and agree) which amounted to 92 individuals with a percentage $30.7 \%$.

The results of the descriptive analysis also showed that the average was 1.22 and the standard deviation was 1.84 , that the approval level (low).

The Sixth Paragraph: Geographic Information Systems (GIS) applications are used to link the study area to other tourist areas within the scope of Cairo governorate. The sample answers were as shown in table 17. 
Table 17. Statistical Analysis (Geographic Information Systems (GIS) applications are used to link the study area to other tourist areas within the Cairo governorate)

\begin{tabular}{|c|c|c|c|c|c|}
\hline & & Iteration & Percentage & Arithmetic mean & Standard deviation \\
\hline \multirow{6}{*}{ Analyzable } & Strongly Disagree & 45 & $\% 15.0$ & \multirow{6}{*}{1.90} & \multirow{6}{*}{1.75} \\
\hline & Disagree & 206 & $\% 68.7$ & & \\
\hline & Neutral & 22 & $\% 7.3$ & & \\
\hline & Agree & 27 & $\% 9.0$ & & \\
\hline & strongly agree & 0 & $0 \%$ & & \\
\hline & Total & 300 & $\% 100.0$ & & \\
\hline
\end{tabular}

Source: SPSS Outputs

Table 18. Statistical Analysis (he extent of economic problems affecting the use of Geographic Information Systems (GIS) applications)

\begin{tabular}{|c|c|c|c|c|c|}
\hline & & Iteration & Percentage & Arithmetic mean & Standard deviation \\
\hline \multirow{6}{*}{ Analyzable } & Strongly Disagree & 18 & $\% 6.0$ & \multirow{6}{*}{3.95} & \multirow{6}{*}{.984} \\
\hline & Disagree & 65 & $\% 21.7$ & & \\
\hline & Neutral & 123 & $\% 41.0$ & & \\
\hline & Agree & 71 & $\% 23.7$ & & \\
\hline & strongly agree & 23 & $\% 7.7$ & & \\
\hline & Total & 300 & $\% 100.0$ & & \\
\hline
\end{tabular}

Source: SPSS Outputs

It is noted from table 17 data that the total of the opinions of the sample (Strongly Disagree and Disagree) of 251 individuals with a percentage $83.7 \%$ tend to be disapproving compared to the total of the opinion (strongly agree and agree) which was 27 individuals with a percentage $9.0 \%$.

The results of the descriptive analysis also showed that the average was 1.90 and the standard deviation was 1.75 , that the approval level is (low).

The Seventh Paragraph: The extent of economic problems affecting the use of Geographic Information Systems (GIS) applications. The sample answers were as shown in table 18.

It should be noted from table 18 data that the opinions of the sample (Agree and strongly agree) numbered 94 individuals with a percentage $31.4 \%$ are opinions that tend to be approved compared to the total opinions (Strongly Disagree and disagree) which amounted to 83 individuals with a percentage $27.7 \%$.

The results of the descriptive analysis also showed that the average was 3.95 and the standard deviation was .984 , i.e. the approval level (high).

The Eighth Paragraph: The extent of regulatory problems facing the use of Geographic Information Systems (GIS) applications to plan the study area from the tourist side. The sample responses were as shown in table 19. 
Table 19. Statistical Analysis (The extent of regulatory problems facing the use of Geographic Information Systems (GIS) applications to plan the study area from the tourist side)

\begin{tabular}{|c|c|c|c|c|c|}
\hline & & Iteration & Percentage & Arithmetic mean & Standard deviation \\
\hline \multirow{6}{*}{ Analyzable } & Strongly Disagree & 12 & $\% 4.0$ & \multirow{6}{*}{3.78} & \multirow{6}{*}{.980} \\
\hline & Disagree & 28 & $\% 9.3$ & & \\
\hline & Neutral & 27 & $\% 9.0$ & & \\
\hline & Agree & 179 & $\% 59.7$ & & \\
\hline & strongly agree & 54 & $\% 18.0$ & & \\
\hline & Total & 300 & $\% 100.0$ & & \\
\hline
\end{tabular}

Source: SPSS Outputs

Table 20. Statistical Analysis (There are technical problems facing the use of information system applications in general.)

\begin{tabular}{|c|c|c|c|c|c|}
\hline & & Iteration & Percentage & Arithmetic mean & Standard deviation \\
\hline \multirow{6}{*}{ Analyzable } & Strongly Disagree & 0 & $0 \%$ & \multirow{6}{*}{4.21} & \multirow{6}{*}{.606} \\
\hline & Disagree & 3 & $\% 1.0$ & & \\
\hline & Neutral & 21 & $\% 7.0$ & & \\
\hline & Agree & 186 & $\% 62.0$ & & \\
\hline & strongly agree & 90 & $\% 30.0$ & & \\
\hline & Total & 300 & $\% 100.0$ & & \\
\hline
\end{tabular}

Source: SPSS Outputs

It is noted from table data (19) that the opinions of the sample (Agree and strongly agree) of 233 individuals with a percentage $77.7 \%$ tend to be approved compared to the total of the two opinions (I do not strongly and Disagree) which amounted to 40 individuals with a percentage $13.3 \%$. The results of the descriptive analysis also showed that the average was 3.78 and the standard deviation was 0.980 that the approval level is high.

The Ninth Paragraph: There are technical problems facing the use of information system applications in general. The result of the sample opinions was as shown in table 20.
It is noted from table data (20) that the total of the opinions of the sample (strongly agree and Agree) of 276 individuals with a percentage $92.0 \%$ tend to be approved compared to the total of the opinion (Disagree) which was 3 individuals with a percentage $1 \%$. The results of the descriptive analysis also showed an average of 4.21 and the standard deviation of .606 that the approval level is very high.

The Tenth Paragraph: The size of the demand for the study area is suitable with its tourist facilities. The result of the opinions of the sample was as shown in table 21. 
Table 21. Shows statistical analysis (The size of the demand for the study area is suitable with its tourist facilities)

\begin{tabular}{|c|c|c|c|c|c|}
\hline & & Iteration & Percentage & Arithmetic mean & Standard deviation \\
\hline \multirow{6}{*}{ Analyzable } & Strongly Disagree. & 85 & $\% 28.3$ & \multirow{6}{*}{1.16} & \multirow{6}{*}{1.63} \\
\hline & Disagree. & 182 & $\% 60.7$ & & \\
\hline & Neutral & 30 & $\% 10.0$ & & \\
\hline & Agree & 3 & $\% 1.0$ & & \\
\hline & strongly agree. & 0 & $0 \%$ & & \\
\hline & Total & 300 & $\% 100.0$ & & \\
\hline
\end{tabular}

Source: SPSS Outputs

It is noted from table 21 data that the total of the opinions of the sample (Strongly Disagree and disagree) of 267 individuals with a percentage $89.0 \%$ tend to be disapproving compared to the total of the opinion (strongly agree and agree) which was 3 individual scoring $1 \%$.

The results of the descriptive analysis also showed that the average was 1.16 and the standard deviation was 1.63 , that the approval level is (low).

\section{Conclusions}

This paper has reached several results; the need to take advantage of the applications of Geographic Information Systems (GIS) tourism planning technology to support good decision-making, and the preparation and implementation of development plans at faster rates and higher quality. The need to take care of the processing of qualified experts in Geographic Information Systems (GIS) technologies, and their applications in ministries and authorities to form a broad base of human competencies to raise technical developments and increase market needs. Also, it is important to establish a central geographical tourism database at the local level with basic data with mechanisms and responsibilities for modernization, to prevent duplication of efforts and reduce the time, effort and cost incurred by tourism development projects to prepare the databases necessary for the completion of their projects. Strengthening the Ministry of Tourism and Antiquities with this technology, which has become widely used globally to save time, effort and money. Coordination between the administrative levels in the concerned ministries with of archaeological and tourist sites, to avoid duplication of decisions. Raising awareness of the importance of using Geographic Information Systems (GIS) in tourism planning, especially for decision makers. Attention to the need to train the human resources on the basics and concepts of Geographic Information Systems (GIS) science. Establish special units within each organization that develops and builds this modern technology"
Geographic Information Systems (GIS)"according to each organization and its applications. The need to use Geographic Information Systems (GIS) in the monuments documentation by transferring all images, data and written inscriptions on them and containing them in pictures and video, to form a database to become available to the tourist, researcher and planner. The need to take advantage of the tourism and archaeological sites of the study area (Fatimid Cairo) to increase the volume of the tourist demand. The need to face all obstacles, whether economic, regulatory or technical, facing the application of geographical information systems at the national level or at the level of the study area (Fatimid Cairo).

\section{REFERENCES}

[1] Abdo, A.H., 2019. Digital Heritage Applications and its Impact on Cultural Tourism. Journal of Association of Arab Universities for Tourism and Hospitality, 17(1), pp.37-50.

[2] Aminu, M., Ludin, A.N.B.M., Matori, A.N., Yusof, K.W., Dano, L.U. and Chandio, I.A., 2013. A spatial decision support system (SDSS) for sustainable tourism planning in Johor Ramsar sites, Malaysia. Environmental earth sciences, 70(3), pp.1113-1124.

[3] Burrough, P.A., McDonnell, R., McDonnell, R.A. and Lloyd, C.D., 2015. Principles of geographical information systems. Oxford university press.

[4] Dangol, A. and Hacigüzeller, P., 2021. Spatializing the Sagalassos Integrated Information System. In International ANAMED Annual Symposium (pp. 77-87). Koç University Press.

[5] Devkota, B., Miyazaki, H., Witayangkurn, A. and Kim, S.M., 2019. Using Volunteered Geographic Information and Nighttime Light Remote Sensing Data to Identify Tourism Areas of Interest. Sustainability, 11(17), p.4718.

[6] Kates, A.W. and Coryn, C.L., 2021 Use of Geographic Information Systems by American Evaluation Association Members in their Professional Practice. Journal of MultiDisciplinary Evaluation, 17(38), pp.33-49. 
[7] Krois, J. and Schulte, A., 2014. GIS-based multi-criteria evaluation to identify potential sites for soil and water conservation techniques in the Ronquillo watershed, northern Peru. Applied Geography, 51, pp.131-142.

[8] Kurowksa, K., Marks-Bielska, R., Bielski, S., Aleknavičius, A. and Kowalczyk, C., 2021. Geographic Information Systems and the Sustainable Development of Rural Areas. Land, 10(1), p.6.

[9] Lü, G., Batty, M., Strobl, J., Lin, H., Zhu, A.X. and Chen, M., 2019. Reflections and speculations on the progress in Geographic Information Systems (GIS): a geographic perspective. International journal of geographical information science, 33(2), pp.346-367.

[10] Maldonado-Erazo, C.P., Álvarez-García， J., Río-Rama, M.D.L.C.D. and Durán-Sánchez, A., 2021. Scientific Mapping on the Impact of Climate Change on Cultural and Natural Heritage: A Systematic Scientometric Analysis. Land, 10(1), p.76.

[11] Minasi, S.M., Lohmann, G. and Valduga, V., 2020. Geographic Information Systems are critical tools to manage wine tourism regions. Tourism Geographies, pp.1-22.

[12] Ministry of Culture, 2015. The Guide of Islamic Monuments in Cairo City, Supreme Council of Antiquities, 5th edition, Egypt.

[13] Morsi, M. Hussain, 2008. The Islamic Monuments of al-Jamalia district in the Ottoman period and its Touristic Activation, M.Sc. Thesis (Unpublished), Faculty of Tourism and Hotels, Helwan University, Egypt.
[14] Moyle, C.L., Moyle, B. and Burgers, H., 2020 Entrepreneurial strategies and tourism industry growth. Tourism Management Perspectives, 35, p.100708.

[15] Abdel Razik, Ahmed, 2009. The Islamic Architecture in Egypt from the Arab conquest till the Mamluk period (21-923 A.H./641-1517 A.D.), Dar Al-FkrAlaraby, $1^{\text {st }}$ edition, Egypt.

[16] Schade, S., Granell, C., Vancauwenberghe, G., Keßler, C., Vandenbroucke, D., Masser, I. and Gould, M., 2020. Geospatial information infrastructures. In Manual of Digital Earth (pp. 161-190). Springer, Singapore.

[17] Tomaszewski, B., 2020. Geographic information systems (GIS) for disaster management. Routledge

[18] Turer, A.K., 2020. The role of three-dimensional geographic information systems in subsurface characterization for hydrogeological applications. Three-dimensional applications in Geographical Information Systems.

[19] Xu, S., 2021. Three-Dimensional Visualization Algorithm Simulation of Construction Management Based on GIS and VR Technology. Complexity, 2021.

[20] Yousefi, M., Kreuzer, O.P., Nykänen, V. and Hronsky, J.M., 2019. Exploration information systems-A proposal for the future use of GIS in mineral exploration targeting. Ore Geology Reviews, 111, p.103005.

[21]Zhou, L., Li, Q., Tu, W. and Wang, C., 2021. A heterogeneous key performance indicator metadata model for air quality monitoring in sustainable cities. Environmental Modelling \& Software, 136, p.104955. 